УДК 35.08

DOI https://doi.org/10.32838/TNU-2663-6468/2021.3/20

\title{
Фурдик В.Д.
}

Національна академія державного управління при Президентові України

\section{ДЕРЖАВНЕ РЕГУЛЮВАННЯ ВІЙСЬКОВО-МЕДИЧНОЇ РЕФОРМИ ТА ПІДГОТОВКИ КЕРІВНИКІВ У СФЕРІ ВІЙСЬКОВОЇ МЕДИЦИНИ}

\begin{abstract}
У статті висвітлено питання щодо процесу реформування військової медицини, а саме структурно-організаційної перебудови й формування управлінської ланки иієё системи $з$ метою підвищення результативності, якості й ефективності ї̈ функиіонування. Проаналізовано державне регулювання підготовки керівників у сфері військової медицини. Відображено державну політику в розвитку системи підготовки керівників у сфері охорони здоров'я. Визначено основні тенденції дієвості, результативності й ефективності військово-медичних управлінців відповідно до стандартів військової медичини країн НАТО. Умови реформування галузі охорони здоров'я, де одним із головних питань залишається підготовка керівних кадрів, зокрема, для військових лікувальних закладів. Сьогодні основні тяготи медичного забезпечення військовослужбовиів, а також вирішення завдань виживання відповідних військових формувань покладені на плечі їх керівників. Ці ж проблеми притаманні й системі ичвільної медииини. Попередня система організації медичної забезпечення вимагала від керівника насамперед «пробивних здібностей», сьогодні, крім них, керівник повинен мати гарну підготовку з організації, економіки охорони здоров'я, роботи з кадрами й багатьма іншими питаннями, які йому доводиться постійно вирішувати в повсякденній діяльності. Воєнно-медична доктрина Украӥни стала «дорожньою картою» для розбудови організаційних основ системи військової охорони здоров'я, а в перспективі й модернізаиї системи підготовки керівних кадрів. Питання налагодження управління у сфері військової медииини визнане одним із провідних положень - створення єдиної системи проведення санітарно-гігієнічних і протиепідемічних заходів, яку може забезпечити якісний кадровий потенціал управлінців і механізм їх призначення на відповідні керівні посади. Причинами, які зумовили проблеми з медичним забезпеченням у зоні АТО й ООС, стали брак необхідних сил і засобів, а також відсутність взаємодії та узгодженості в діях медичних служб різних військових формувань і системи цивільної охорони здоров'я, у чому простежувалися управлінські проблеми та брак професійних управлінських кадрів медичної служби Збройних Сил України.
\end{abstract}

Ключові слова: державне регулювання, підготовка, військово-медичні кадри, медична сфера, керівник, управлінець, Командування Медичних сил.

Постановка проблеми. На Сході України восьмий рік іде війна. Перебіг військових подій зумовлює потребу реформування Збройних Сил (далі - 3С) України, зокрема, у структурно-організаційному питанні, ураховуючи стандарти країн НАТО. Реформування потребує відповідних змін у межах родів, видів і сил ЗС України. Актуальним це питання є й для військової медицини та їі організаційної структури в системі 3С України, яке загострює тему браку професійних кадрів. Ці дві проблеми (структурно-організаційна й кадрова) реформування системи військової медицини, окресленні у Військо-медичній доктрині України, висувають на порядок денний вагомість підготовки іiі управлінської ланки.

Аналіз останніх досліджень i публікацій. Питанням структурно-організаційної перебу- дови військової медицини України та організації управління всіма ланками цієї системи в наукових працях приділяли увагу В.О. Жаховський, В.Г. Лівінський, В.Я. Білий, В.Б. Андронатій, О.Ю. Булах. Переважно їхні праці торкалися організаційних проблем у військовій медицині України до початку їі реформування. Існує потреба в дослідженні менеджерських питань у цій сфері та проблем підготовки й комплектування професійних медичних кадрів. Поряд із цим потрібно зазначити, що структурно-організаційні й кадрові питання у військовій медицині України мало досліджені в управлінській науці.

Постановка завдання. У статті автор ставить перед собою мету - узгодити два проблемні питання в процесі реформування військової медицини: структурно-організаційної перебудови й формування управлінської ланки цієї системи 3 
метою підвищення результативності, якості та ефективності їі функціонування.

Виклад основного матеріалу дослідження. В Україні стартувала медична реформа за законом, що започатковує зміни в цивільному іiі секторі. Військова медицина, хоч і набула унікального досвіду за час АТО й ООС, теж потребує продовження динамічної організаційно-структурної трансформації та в питанні підготовки керівних кадрів у цій сфері.

Медична служба ЗС України мала можливість здійснювати медичне забезпечення під час бойових дій, але проведені в попередні роки «перманентні реформи» як у самій службі, так і в усій системі охорони здоров'я призвели до зниження iii спроможностей щодо реального медичного забезпечення військ у польових умовах: скорочені організаційно-штатні структури, формування яких передбачалося в особливий період; до критичного мінімуму скорочені медичні посади в медичних підрозділах i військово-медичних закладах; медична техніка, комплектно-табельне оснащення, санітарно-технічне обладнання застаріли; санітарний транспорт практично відсутній тощо.

Усе це ускладнилося умовами реформування всієї галузі охорони здоров' я, де одним із головних питань залишається підготовка керівних кадрів, зокрема, для військових лікувальних закладів. Сьогодні основні тяготи медичного забезпечення військовослужбовців, а також вирішення завдань виживання відповідних військових формувань покладені на плечі їх керівників. Ці ж проблеми притаманні й системі цивільної медицини. I, якщо попередня система організації медичної допомоги вимагала від керівника насамперед «пробивних здібностей», сьогодні, крім них, керівник повинен мати гарну підготовку 3 організації, економіки охорони здоров'я, роботи 3 кадрами й багатьма іншими питаннями, які йому доводиться постійно вирішувати в повсякденній діяльності.

Водночас далеко не всі керівники мають такі знання. Ця вада багато в чому пов'язана 3 відсутністю якісних систем призначення на керівну посаду [1, с. 66] і підготовки керівних кадрів. Це саме стосується й підготовки та призначення керівних кадрів медичної служби ЗС України.

Основними причинами, які зумовили проблеми 3 медичним забезпеченням у зоні АТО й ООС, стали брак необхідних сил і засобів, а також відсутність взаємодії та узгодженості в діях медичних служб різних військових формувань і системи цивільної охорони здоров'я, у чому простежувалися управлінські проблеми та брак професійних управлінських кадрів медичної служби 3С України. Їх розв’язання й забезпечення своєчасною медичною допомогою поранених військовослужбовців і цивільного населення, відповідне якісне лікування можливі за умов створення єдиної державної системи військової медицини, яка об'єднала б зусилля всіх учасників у чітко працюючий механізм [2, с. 9].

Для розв'язання цих проблем був потрібний документ державного рівня - Воєнно-медична доктрина України. Вона затверджена Постановою КМ України від 31 жовтня 2018 р. № 910 [3]. У доктрині визначена структура воєнно-медичної системи: медичні служби Збройних Сил, МВС, Національної гвардії, СБУ, Держприкордонслужби, Держспецзв'язку, Служби зовнішньої розвідки, Держспецтрансслужби. У ній визначено поняття «єдиний медичний простір» як система організації надання медичної допомоги, яка об'єднує всі медичні ресурси держави спільним управлінням і визначеними механізмами фінансування й забезпечує доступність, якість та ефективність усіх видів медичної допомоги всім громадянам України, зокрема й військовослужбовцям. Сдиний медичний простір передбачає інтеграцію в нього системи медичного забезпечення військ для функціонального поєднання сил і засобів медичних служб і системи охорони здоров'я цивільного населення 3 метою максимальної реалізації їх спроможностей щодо ефективного медичного забезпечення військ зі збереженням організаційної самостійності. У цьому просторі управління системою медичного забезпечення військ здійснюється в єдиній системі управління військами. У 4 розділі доктрини визначені вимоги щодо підготовки військово-медичних кадрів. Отже, Воєнно-медична доктрина України стала «дорожньою картою» для розбудови організаційних основ системи військової охорони здоров'я, а в перспективі й модернізації системи підготовки керівних кадрів. У доктрині питання налагодження управління у сфері військової медицини визнане одним із провідних положень: створення єдиної системи проведення санітарно-гігієнічних і протиепідемічних заходів, яку може забезпечити якісний кадровий потенціал управлінців і механізм їх призначення на відповідні керівні посади.

Події на сході України виявили низку серйозних проблем $\mathrm{y}$ медичному забезпеченні 3С України й інших військових формувань, зокрема відсутність взаємодії між їхніми медичними службами та цивільними закладами 
охорони здоров'я, що негативно відобразилося на стані медичного забезпечення військ загалом, своєчасності та якості надання медичної допомоги пораненим і їх лікування зокрема [6]. Практика показала повну відсутність єдиної системи управління та координації дій медичних служб ЗС України, інших військових формувань і системи цивільної охорони здоров'я України. Ця проблема також актуалізує питання підготовки не просто керівних кадрів, а управлінців у сфері військової медицини.

До складу системи Медичної служби 3С України до 2017 р. належало 5 військовомедичних центри, 14 військових і гарнізонних військових шпиталів; 3 центри медичної реабілітації й санаторного лікування; 5 військово-лікарських комісій; 7-ома і 8-ма окремі автомобільні санітарні роти; 2 центральні медичні склади, 2 медичні склади й 4 центри формування та зберігання медичної техніки й майна; санітарно-епідеміологічне управління, 5 регіональних і 2 територіальні санітарно-епідеміологічні загони, 4 військові мобільні шпиталі; медичні служби військових частин, кораблів, вищих військових навчальних закладів; медичні роти й медичні пункти; Українська військово-медична академія [11].

У військовій медицині у 2017 р. розпочалася суттєва структурно-організаційна та кадрова реформа. До 2017 р. військово-медична служба поділялася на 2 частини: Медична служба Міністерства оборони України й медична служба 3С України. Структурно-організаційне реформування військової медицини розпочалося у 2017 р. (в аспекті іiї організаційної централізації в поєднані зі структурно-організаційною децентралізацією), коли було створено Головне військово-медичне управління ЗС України. Йому підпорядковувалися військові шпиталі, санаторії та медичні склади, а медична служба військових частин підпорядковувалася їх командирам.

У лютому 2020 р. було утворено Командування Медичними силами 3С України. Така трансформація стала логічним продовженням реформування ЗС України, яке передбачало запровадження інституту Головнокомандуючого, у зв'язку з чим розмежовувалися функції МО України й Головнокомандуючого, якому підпорядковується Генеральний штаб ЗС України, Об'єднаний штаб, Командувачі родів, видів і сил ЗС України. Уся територія України поділена на чотири оперативні командування («Захід», «Північ», «Схід», «Південь»), у кожному з яких сформовані Командування сухопутних військ і
Повітряних сил. Командування військово-морських сил сконцентровані в західній і південній військово-морських базах. Крім того, сформовані Десантно-штурмові війська й Сили спеціальних операцій. За всю медицину на території кожного 3 чотирьох оперативних командувань будуть відповідати військово-медичні клінічні центри, у яких буде створено оперативно-медичні управління, які будуть займатися всією медициною, яка обслуговує всі роди військ. Їх провідною метою $є$ те, що підготовка медичних кадрів має бути однакова незалежно від роду військ, тобто на них покладається функція навчання, підвищення кваліфікації військових медиків [8]. Проблему у військовій медицині становить те, що військові шпиталі укомплектовані кадрами на 95-98\%, а медичні служби ЗС України - на 40-60\% [9]. У шпиталях медики не так швидко втрачають кваліфікацію, як у військовій ланці медичної служби. Ці диспропорції покликані долати оперативно-медичні управління.

Старший радник з медичних питань від США та інших країн НАТО Джим Кехілл в інтерв'ю Інформагентству АрміяInform зазначав, що це було дуже сміливе рішення, підкресливши, що під час реформування вдалося створити мобільні госпіталі, реорганізувати хірургічну частину медслужб бригад. Поряд із цим утворено групу медичної евакуації, на яку покладається функція, яку до неї виконували сили бригад, волонтерів і громадських організацій [7].

Між Головним військово-медичним управлінням 3С України й Командуванням Медичними силами ЗС України існує декілька структурноорганізаційних відмінностей:

1. Головне управління мало подвійне nidnoрядкування (загальне підпорядкування Міністру оборони України й оперативне підпорядкування в питаннях планування, підготовки, застосування й управління - Генеральному штабу - Головнокомандуючому 3С України); а Командування Медичними силами - Головнокомандуючому ЗС України;

2. Структурна відмінність: у Головного управління функціональна структура управління, для якої властива спеціалізація структур управління (командування, оперативно-медичне управління, лікувально-профілактичне, медичне постачання, персонал, підготовка та міжнародне співробітництва, а також фінансово-економічна служба, адміністративний відділ, служба охорони державної таємниці), а Командування Медичних сил лінійно-функціональна структура управління, для 
якої властива лінійна вертикаль (ієрархія) управління та спеціалізація управлінської праці за функціональними ознаками (керівнику організації безпосередньо підпорядковані заступники за функціями), тобто об'єднання функціональних структур єдиним командуванням.

3. За Головного управління різноманітні структури медичної служби підпорядковувалися відповідним військовим підрозділам, а Командування Медичних сил - відбулася централізація управління й уся система військової медичної служби перейшла під керівництво Командувача Медичними силами, яким став генерал-майор медичної служби Ігор Хоменко (сьогодні Командування тимчасово очолює полковник медичної служби Сергій Халік). Отже, у кадровому питанні військові медики підпорядковуються вже не тим військовим підрозділам, при яких вони функціонують, а виключно Командуванню Медичними силами, відповідно, за підготовку медичних кадрів, зокрема й керівної їх ланки, тепер відповідає Командування через оперативно-медичні управління.

Сьогодні в медичній службі нараховується близько 22 тисяч осіб і за чисельністю вона третя після Сухопутних військ і Повітряних сил. На думку генерал-майора медичної служби Ігоря Хоменко, кадровою політикою і підготовкою кадрів у військовій медицині мають займатися військові медики [9], що забезпечить оптимальність, якість та ефективність іiі функціонування. Він зазначав, що до 2025 року Командування планує створити медичні роти як окремі частини, які будуть підпорядковані командувачу медичних сил, що дасть змогу доукомплектовувати бойові частини не окремими людьми, а цілими ротами, як це вже впроваджено в мобільних госпіталях.

Другим головним кадровим напрямом Командування Медичними силами його колишній очільник визначав те, що необхідно проводити роботу 3 військовими кафедрами при медичних університетах. Він наголошував, що при Національному медичному університеті ім. Богомольця створений військовий факультет, але після цього факультету у військову медицину приходить лише 5-6 осіб. Планується ввести нові принципи підготовки й укладання контракту. Ігор Хоменко наводив приклад Німеччини, де юнак, який виявив бажання бути військовим лікарем, вступає на військово-медичний факультет, підписує контракт на 16 років. Цим Німеччина як держава бере на себе зобов'язання в цій підготовці. Саме тому планується взяти під контроль підготовку медичних фахівців і кадрову політику, тоді з військ менше буде звільнятися молоді, яка зараз не бачить перспективи служби. Тому кадровий менеджмент уважається одним із основних, який забезпечить молоді, яка прийшла у війська після закінчення військових факультетів медичних університетів та Української військово-медичної академії, прослуживши 2-3 роки, перспективу здобути фах за різними напрямами, а не тільки лікаря загальної практики. Крім того, в Академії у 2020 р. збільшили набір майже вдвічі лікарів загальної практики, держзамовлення з 40 зросло до 80 осіб [9].

Відповідно до класифікації професій, зазначених у Національному класифікаторі України [5], за галузевим спрямуванням (стосовно охорони здоров'я) професії поділяють на такі класи: керівники, професіонали, фахівці й технічні службовці. Відповідно до класифікатора, керівники професії у сфері охорони здоров'я пов'язані 3 визначенням і формуванням державної політики в галузі охорони здоров'я, його законодавчого регулювання, вищого державного управління, керівництва підприємств та об'єднань підприємств, установ, організацій і їхніх підрозділів незалежно від форм власності й видів економічної діяльності. Від працівника кваліфікації лікаря вимагається спеціалізація 3 організації охорони здоров'я та відповідних спеціальних знань і навичок, які необхідні для виконання різноманітних управлінських функцій.

Управлінці в розвинутих країнах світу - це фахівці з економічною і юридичною освітою медичні менеджери, а в Україні більшість відповідних управлінців - фахівці без досвіду й навичок управління, які мають виключно медичну освіту, зокрема й у сфері військової медицини.

Медичні менеджери поділяються на управлінців загальної кваліфікації й на управлінців-спеціалістів. На управлінців загальної кваліфікації покладається відповідальність за загальне управління медичним закладом, а на управлінців-спеціалістів - ефективне управління специфічними напрямами: аналіз управлінських рішень і стратегій, зокрема, у системі військової медицини, фінансів і складання бюджету, управління людськими ресурсами [6].

3 огляду на це, потрібно зазначити, що в системі військової медицини існують вагомі особливості щодо підготовки керівних кадрів. Якщо медичну освіту можна отримати в цивільних навчальних закладах, то отримати управлінські права у військовій медицині з 10-х років XXI ст. уже не можливо. 
В Українській військово-медичній академії із цією метою у 2012 р. на кафедрі організації медичного забезпечення збройних сил розпочата підготовка офіцерів військового управління оперативно-тактичного рівня за освітньо-кваліфікаційним рівнем «Магістр військового управління». Наказом Міністерства освіти і науки України від 24 травня 2019 р. № 724 затверджений стандарт вищої освіти за спеціальністю 253 «Військове управління (за видами збройних сил)» галузь знань 25 «Воєнні науки, національна безпека, безпека державного кордону» для другого (магістерського) вищого рівня освіти. В освітній кваліфікації має зазначатися вид або рід ЗС України, у професійній кваліфікації зазначається «офіцер оперативного рівня». Офіцери відповідної кваліфікації отримують право на подальше здобуття вищої військової стратегічної освіти [10].
Висновки. Таким чином, особливість кадрової політики у військовій медицині в аспекті підготовки iii управлінського потенціалу передбачає, що керівник має буди гнучким у професійній діяльності, добре освіченим, мати професійні знання, уміти мислити системно й аналітично, орієнтуватися на результати, бути комунікативним, мати бажання до саморозвитку й відкритим до нових знань. Управлінець повинен бути готовим до реалізації рішень зі складних завдань, забезпечувати стабільність структури, яку очолює. Це особливо важливо для військово-медичних управлінців за умов структурноорганізаційного реформування ЗС України, зокрема сфери військової медицини, перед якою постають нові завдання в аспекті потреб підвищення іiі дієвості й результативності, якості й ефективності, що диктують стандарти військової медицини країн НАТО й передусім США та Німеччини.

\section{Список літератури:}

1. Лашкул 3.В. Особливості підготовки керівників охорони здоров'я в сучасних умовах. Матеріали науково-практичної конференції (22 квітня 2015 р., Київ). Київ, 2015. С. 66-69.

2. Білий В.Я., Жаховський В.О., Лівінський В.Г. Трансформування та розвиток Збройних Сил України. Наука і оборона. 2015. № 1. С. 9-14.

3. Про затвердження Воєнно-медичної доктрини України : Постанова Кабінету Міністрів України від 31 жовтня 2018 р. № 910 / Кабінет Міністрів України. URL: https://zakon.rada.gov.ua/laws/show/910-2018$\% \mathrm{D} 0 \% \mathrm{BF}$ Text.

4. Система медичного забезпечення Збройних Сил України: сучасний стан і напрями розвитку 3 огляду на тенденції змін у порядку застосування військ / В.Б. Андронатій, В.О. Жаховський, О.Ю. Булах, В.Г. Лівінський. Наука і оборона. 2014. № 3. С. 23-29.

5. Національний класифікатор України. Класифікатор професій ДК 003:2010 : Наказ Держспоживстандарту України від 28.07.2010 № 327, чинний від 01.11.2010.

6. Hialth CareAdministrator. Retrievid 11 September 2012. URL: www.msheathcareers.com/careers. healthcareadmin.htm.

7. Військово-медична реформа - одна з трьох основних змін у всіх урядових відомствах України. Інтерв'ю старшого радника з медичних питань від США та інших країн Альянсу Джим Кехілл спеціально для Інформагентства АрміяInform. URL: https://www.mil.gov.ua/news/2019/09/30/vijskovo-medichnareforma-odna-z-troh-osnovnih-zmin-v-usih-uryadovih-vidomstvah-ukraini/.

8. Брифінг в АрміяInform начальника Головного медичного управління ЗС України генералмайор медичної служби Ігор Хоменко. URL: https://uprom.info/news/v-zbrojnyh-sylah-ukrayiny-stvorenokomanduvannya-medychnyh-syl/amp/.

9. Командування медичних сил третє за чисельністю в ЗСУ. Інтерв'ю АрміяFM начальник Головного медичного управління 3С України генерал-майор медичної служби Ігор Хоменко (5 березня 2020 р.). URL: http://www.armyfm.com.ua/komanduvannya-medichnih-sil-tretye-za-chiselnistyu-v-zsu/.

10. Про затвердження стандарту вищої освіти за спеціальністю 253 «Військове управління (за видами збройних сил)» для другого (магістерського) рівня вищої освіти : Наказ Міністерства освіти і науки України від 24 травня 2019 р. № 724 / Міністерство освіти і науки України. URL: https://mon.gov.ua/storage/app/ media/vishcha-osvita/zatverdzeni\%20standarty/2019/05/28/253-viyskove-upravlinnya -za-vidami-zbroynikh-silmagistr.pdf.

11. Медична служба Збройних сил України. Вікіnediя. URL: https:/luk.wikipedia.org/wiki/\%D0\%9C\% D0\%B5\%D0\%B4\%D0\%B8\%D1\%87\%D0\%BD\%D0\%B0 \%D1\%81\%D0\%BB\%D1\%83\%D0\%B6\%D0\%B1 $\% \mathrm{D} 0 \% \mathrm{~B} 0 \_\% \mathrm{D} 0 \% 97 \% \mathrm{D} 0 \% \mathrm{~B} 1 \% \mathrm{D} 1 \% 80 \% \mathrm{D} 0 \% \mathrm{BE} \% \mathrm{D} 0 \% \mathrm{~B} 9 \% \mathrm{D} 0 \% \mathrm{BD} \% \mathrm{D} 0 \% \mathrm{~B} 8 \% \mathrm{D} 1 \% 85 \_\% \mathrm{D} 1 \% 81 \% \mathrm{D} 0 \% \mathrm{~B}-$ 8\%D0\%BB_\%D0\%A3\%D0\%BA\%D1\%80\%D0\%B0\%D1\%97\%D0\%BD\%D0\%B8. 


\section{Furdik V.D. STATE REGULATION OF MILITARY MEDICAL REFORM AND TRAINING OF LEADERS IN THE FIELD OF MILITARY MEDICINE}

The article covers the issues of the process of reforming military medicine, namely the structural and organizational restructuring and formation of the management of this system in order to improve the effectiveness, quality and efficiency of its operation. The state regulation of training of leaders in the field of military medicine is analyzed. The state policy in the development of the system of training of managers in the field of health care is reflected. The main trends in the effectiveness, efficiency and effectiveness of military medical managers in accordance with the standards of military medicine of NATO countries are identified. Conditions for reforming the health sector, where one of the main issues remains the training of managers, in particular, for military medical institutions. Today, the main burdens of medical care for servicemen, as well as solving the problems of survival of the relevant military formations are the responsibility of their leaders. The same problems are inherent in the system of civil medicine. The previous system of medical care required from the head, first of all, "breakthrough abilities", today, in addition to them, the head must have good training in organization, health economics, human resources and many other issues that he has to constantly address in their daily lives. The military medical doctrine of Ukraine has become a "road map" for building the organizational foundations of the military health care system, and in the future to modernize the system of training. The issue of establishing management in the field of military medicine is recognized as one of the leading provisions - the creation of a single system of sanitary and anti-epidemic measures, which can provide quality human resources managers and the mechanism of their appointment to relevant management positions. The reasons for the problems with medical care in the ATO and OOS zone were the lack of necessary forces and means, as well as the lack of interaction and coordination in the actions of medical services of various military formations and the civilian health care system. managerial staff of the medical service of the Armed Forces of Ukraine.

Key words: state regulation, training, military medical personnel, medical sphere, head, manager, Medical Forces Command. 